\title{
Pengaruh Pemberian Tepung Kiambang (Salvinia molesta) Terfermentasi dalam Ransum terhadap Performa Ayam Jawa Super (Joper)
}

\section{Effect of Giving Fermented Kiambang (Salvinia Molesta) Flour in the Ration on Performance of Super Javanese Chicken (Joper)}

\author{
H Angelina ${ }^{1}$, Nurhayati ${ }^{1 *}$, dan A A Candra ${ }^{1}$ \\ ${ }^{1}$ Jurusan Peternakan Politeknik Negeri Lampung, \\ Jln. Soekarno Hatta No 10 Rajabasa Bandar Lampung, 35144 \\ *E-mail korespondensi : nurhayatipoltek@yahoo.com
}

\begin{abstract}
Kiambang is a plant that grows in lakes, ponds, rivers, or ditches. Kiambang has the potential as animal feed because of the large number of kiambang which is fast growing and has not been widely used as animal feed. Kiambang is still an unconventional feed that can be used as an alternative feed because it contains good nutrition. This study aims to analyze the effect of fermented kiambang (Salvinia molesta) flour on the performance of super Javanese chicken (joper). The research was conducted at the Lampung State Polytechnic farm. Experimental research used 100 chicken divided in two treatments, control with $100 \%$ commercial feed and the second treatment with $10 \%$ fermented kiambang flour. The result giving 10\% fermented kiambang flour (Salvinia molesta) in the ration does not affect the performance on the joper chickens.
\end{abstract}

Keywords: joper chicken, kiambang, performance

Diterima: 1 Juli 2021, disetujui 15 Desember 2021

\section{PENDAHULUAN}

Kiambang merupakan tanaman yang tumbuh di danau, kolam, sungai, selokan atau parit. Kiambang berpotensi sebagai pakan ternak karena banyaknya kiambang yang cepat pertumbuhannya dan belum banyak dimanfaatkan sebagai pakan ternak. kiambang masih termasuk pakan inkonvensional yang bisa dijadikan sebagai pakan alternatif karena kiambang mengandung nutrisi yang baik. Kiambang memiliki kandungan protein kasar 15,9 \%, serat kasar 16,8 \%, Ca 1,27 \%, dan P 0,798 \% (Rosani, 2002), dan zat aktif seperti asam lemak esensial, pigmen xanthofil mencapai 1.000 ppm (Akter et al., 2011), serta beta-karoten 111,24 $\mathrm{mg} / \mathrm{kg}$ BK (Anderson et al., 2011). Setiowati (2001) telah melaporkan bahwa kandungan energi metabolisme kiambang adalah $2.200 \mathrm{kkal} / \mathrm{kg}$. Keunggulan kiambang karena mengandung protein yang lumayan tinggi, namun kandungan serat kasar yang tinggi. Maka perlu dilakukannya teknologi pengolahan pakan yaitu dengan teknologi fermentasi. Kandungan kiambang setelah difermentasi kandungan protein dan serat kasar pada kiambang (Salvina molesta) menjadi 18,8 \% dan 11,6 \% (Zaman, 2013). Proses fermentasi kiambang mampu menurunkan serat kasar dan meningkatkan protein kiambang. Fermentasi kiambang dapat diaplikasikan untuk pakan ayam joper. Penambahan fermentasi kiambang dalam ransum mampu memenuhi kebutuhan protein ayam joper. Kebutuhan nutrisi ayam joper yaitu protein kasar (PK) sebesar 14--17\%, Energi Metabolis (EM) sebesar 2.600--2.700 Kkal/kg, Ca 0,9\%, P 0,45\% dan dilengkapi dengan mineral lain serta vitamin yang mencukupi kebutuhan (Mangisah et al., 2018). Oleh karena itu penulis ingin menganalisis pengaruh pemberian tepung kiambang terfermentasi dalam ransum terhadap performa ayam 
joper. Tujuan dari penelitian ini adalah mengetahui pengaruh penambahan tepung daun kiambang (Salvinia molesta) terfermentasi pada performa ayam jawa super (Joper).

\section{METODE PENELITIAN}

Bahan yang digunakan pada penelitian ini adalah DOC ayam joper sebanyak 100 ekor, kiambang, molases, ragi tempe, dan pakan komersil, vaksin. Alat yang digunakan pada penelitian ini yaitu gilingan, panci, lampu, instalasi listrik, chick guard, tempat pakan dan minum, timbangan digital, kompor, saringan, dan baskom.

\section{Fermentasi Kiambang}

Kiambang yang basah dikeringkan dengan sinar matahari, setelah kering kemudian digiling halus menjadi tepung. Kiambang tersebut dicampur dengan molases dengan perbandingan $1 \mathrm{~kg}$ kiambang dicampur dengan dua sendok makan molases. Setelah molases tercampur rata dengan kiambang, kiambang tersebut dikukus selama $1 / 2$ jam dan dibiarkan dingin. Setelah dingin, kiambang difermentasi dengan mencampurkannya dengan ragi tempe (1 kg kiambang : $18 \mathrm{~g}$ ragi tempe) dan dimasukkan ke dalam bak fermenter dan ditutup dengan plastik. Proses fermentasi berlangsung secara anaerob selama 7 hari. Setelah dilakukan fermentasi selama 7 hari, kiambang kemudian dicetak menjadi butiran-butiran pellet menggunakan gilingan daging yang dimodifikasi, kemudian dikeringkan menggunakan panas matahari (Zaman, et al. 2013).

\section{Peubah yang Diamati}

Peubah yang diamati meliputi:

1. Konsumsi ransum (gram/ekor) $=$ selisih antara jumlah total pakan yang diberikan dengan jumlah sisa pakan

2. Pertambahan bobot badan (gram/ekor) $=$ menghitung selisih antara bobot badan ayam mingguan dengan bobot badan minggu sebelumnya.

3. Konversi ransum = membagi jumlah total konsumsi ransum $(\mathrm{g})$ dengan pertambahan bobot badan $(\mathrm{g})$. Metode yang telah dipublikasikan sebelumnya harus ditulis sebagai pustaka, hanya modifikasi yang relevan yang harus dijelaskan. Dibuat dalam bentuk paragraf mengalir dan tidak dibuat numbering. Simbol-simbol statistik menggunakan simbol-simbol dan istilah standar misalnya t-test bukan t-hitung.

\section{HASIL DAN PEMBAHASAN}

Hasil penelitian pengaruh pemberian tepung kiambang (Salvinia molesta) terfermentasi dalam ransum terhadap performa ayam jawa super (joper) antara lain: konsumsi ransum, pertambahan bobot badan, dan konversi ransum, disajikan pada Tabel 1.

Tabel 1

\begin{tabular}{lrr}
\hline & \multicolumn{1}{c}{ P0 } & \multicolumn{1}{c}{ P1 } \\
\hline Konsumsi Ransum (g/ekor) & 3607,64 & 3598,95 \\
Pertambahan Bobot Badan (g/ekor) & 741,75 & 734,16 \\
Konversi Ransum & 4,87 & 4,90 \\
\hline
\end{tabular}

\section{Konsumsi Ransum}

Berdasarkan Tabel 1 bahwa konsumsi pakan ayam joper pada kontrol yaitu dengan rata-rata 3607,64 gram dan pada perlakuan dengan rata-rata 3598,95 gram. Selisih perbedaan konsumsi pakan pada kontrol dan perlakuan hanya 8,69 gram. Hasil tersebut menunjukkan bahwa konsumsi pada kontrol lebih tinggi dibandingkan perlakuan. Menurut Wahju (2004) besarnya konsumsi ransum tergantung pada kandungan protein ransum. Pada kandungan nutrisi protein pakan perlakuan dan kontrol pada ransum (sebesar 18,43\% 
dan $18,00 \%$ ) yang hanya selisih $0,43 \%$ serta kandungan energi kontrol dan perlakuan (sebesar $3000 \mathrm{kkal} / \mathrm{kg}$ dan $3100 \mathrm{kkal} / \mathrm{kg}$ ) yang hanya selisih $100 \mathrm{kkal} / \mathrm{kg}$ yang tidak jauh beda, maka dari itu konsumsi ransum pada kontrol dan perlakuan juga tidak jauh berbeda hanya selisih 8,69 gram/ekor. Azizi et al. (2011) menyatakan bahwa dalam suatu pemeliharaan maka ada beberapa faktor yang mempengaruhi konsumsi ransum diantaranya jumlah konsumsi ransum dan kandungan zat makanan pada ransum seperti energi, protein kasar dan serat kasar. Hal ini sepadan dengan penelitian Tampubolon (2012) yang menyebutkan bahwa asupan protein dipengaruhi oleh jumlah konsumsi ransum. Pakan yang energinya semakin tinggi semakin sedikit dikonsumsi demikian sebaliknya bila energi pakan rendah akan dikonsumsi semakin banyak untuk memenuhi kebutuhannya. Kandungan nutrisi pada ransum seperti energi yang jika ayam sudah terpenuhi sesuai kebutuhannya maka ayam akan berhenti mengkonsumsi ransum walaupun tembolok dalam keadaan kosong. Menurut Scott et al. (1982) ayam cenderung meningkatkan konsumsinya jika kandungan energi ransum rendah dan sebaliknya konsumsi akan menurun jika kandungan energi ransum meningkat. Hal ini sejalan dengan hasil penelitian Wahyu (2004) bahwa besar dan bangsa ayam, temperatur lingkungan, tahap produksi, dan energi dalam pakan dapat mempengaruhi konsumsi ransum.

\section{Pertambahan Bobot Badan}

Berdasarkan Tabel 1 didapatkan rataan pertambahan bobot badan pada kontrol yaitu 741,75 gram/ekor dan pada perlakuan 734,16 gram/ekor. Selisih pertambahan bobot badan kontrol dan perlakuan sebesar 7,59 gram. Hal ini menunjukkan pertambahan bobot badan berbanding lurus dengan konsumsi pakan. Hasil rataan tersebut bahwa penambahan bobot badan kontrol lebih tinggi dibandingkan penambahan bobot pada perlakuan. Hal ini dikarenakan konsumsi ransum pada perlakuan (2598,95 gram) lebih rendah dibandingkan kontrol (3607,64 gram) dan kandungan energi dan protein pada pakan kontrol dan perlakuan tidak berbeda jauh. Ichwan (2003) menyatakan bahwa secara umum penambahan berat badan akan dipengaruhi oleh jumlah konsumsi pakan yang dimakan dan kandungan nutrisi yang terdapat dalam pakan tersebut. Hal ini juga didukung oleh Zulfanita (2011) untuk mendapatkan ayam dengan pertumbuhan yang cepat dan produksi yang efisien, maka penyusunan ransum perlu diperhatikan utamanya mengenai kandungan energi dan protein serta keseimbangannya. Perbedaan pertambahan bobot badan antara kontrol dan perlakuan dikarenakan juga kandungan gizi pada pakan berbeda. Hal ini sejalan dengan penelitian Amrullah (2004) kandungan zat gizi yang berbeda pada setiap ransum akan memberikan nilai konsumsi ransum dan bobot badan yang berbeda pula.

\section{Konversi Ransum}

Berdasarkan Tabel 1. Menunjukkan bahwa konversi ransum pada kontrol yaitu 4,8 dan pada perlakuan 4,9. Perbedaan konversi ransum pada kontrol dan perlakuan hanya selisih sedikit yaitu 0,1 . Penelitian ini untuk konversi ransum sedikit lebih rendah dibandingkan pada penelitian Wicaksono et al. (2015) ayam kampung super (umur 3--10 minggu) dengan pemberian ransum adlibitum memiliki nilai konversi ransum 5,0--5,5. Konversi ransum pada perlakuan lebih tinggi dibandingkan kontrol. Hal ini diduga karena palatabilitas ayam pada ransum perlakuan. Palatabilitas ransum dipengaruhi oleh bentuk, bau, rasa dan suhu ransum yang diberikan (Cruch, 1979 dalam Martini, 2002). Semakin tinggi level pemberian tepung fermentasi kiambang maka bau pada ransum akan semakin menyengat dan bentuk ransum yang sedikit halus sehingga memudahkan ayam untuk makan serta kandungan nutrisi energi dan protein pada pakan yang memiliki nilai hampir sama antara ransum perlakuan dengan kontrol. Hasil rataan diatas konversi yang tinggi dikarenakan mengkonsumsi pakan yang banyak namun bobot badan rendah. Hal ini sejalan dengan penelitian Manurung (2011) konversi pakan tinggi disebabkan oleh jumlah pakan yang dikonsumsi tinggi, tetapi pertambahan bobot badan yang rendah. Semakin rendah konversi ransum maka semakin baik kualitasnya, begitupun sebaliknya. 
Angelina et al. : Pengaruh Pemberian Tepung Kiambang (Salvinia molesta) Terfermentasi dalam Ransum terhadap Performa Ayam Jawa Super (Joper)/Peterpan 3 (2): 48-52

\section{KESIMPULAN}

Berdasarkan hasil penelitian dapat disimpulkan bahwa pemberian tepung kiambang (Salvinia molesta) terfermentasi $10 \%$ dalam ransum terhadap performa ayam jawa super (Joper) pada perlakuan pemberian produk fermentasi tidak mempengaruhi konsumsi ransum, pertambahan bobot badan, konversi ransum, dan mortalitas ayam jawa super (Joper).

\section{DAFTAR PUSTAKA}

Akter, M. S. D. Chowdhury, Y. Akter dan M. A. Khatun. 2011. Effect of duckweed (Lemna minor) meal in the diet of laying hen and their performance. Bangladesh Res. Pub. J. 5 (3): 252--261.

Amrullah KI. 2004. Nutrisi Ayam Pedaging. Lembaga Satu Gunung Budi. Bogor

Anderson, K. E., Z. Lowman, A. M. Stomp., dan J. Chang. 2011. Duckweed as a feed ingredient in laying hen diets and its effect on egg production and composition. Int. J. of Poult. Sci.10 (1):4--7.

Azizi, B, G., Sadeghi, A., Karimi, F., dan Abed. 2011. Effect of dietary energy and protein dilution and time of feed replacement from starter to grower on broiler chickens performance. Jurnal of Central European Agriculture. 12 (1) : 44 - 52.

Ichwan. 2003. Membuat Pakan Ayam Ras Pedaging. PT Agromedia Pustaka Utama. Jakarta

Mangisah, I., Sukamto, B., Wahyono, F., Suthama, N., dan Yuniant, D.V. 2018. Perbaikan pakan untuk meningkatkan produktivitas ayam kampung super di Kecamatan Plantungan Kabupaten Kendal. Jurnal DIANMAS 7(1): 35--40.

Manurung, J. E. 2011. Performa Ayam Broiler pada Frekuensi dan Waktu Pemberian Pakan yang Berbeda. Skripsi. Departemen Ilmu Produksi dan Teknologi Peternakan Fakultas Peternakan. Institut Pertanian. Bogor.

Martini. 2002. Pemanfaatan Kulit Buah Coklat sebagai Pakan Alternatif dalam Ransum Broiler. Skripsi. Fakultas Peternakan Universitas Andalas. Padang.

Rosani, U. 2002. Performa Itik Lokal Jantan Umur 4-8 Minggu dengan Pemberian Kayambang (Salvinia molesta) dalam Ransumnya. Jurusan Ilmu Nutrisi dan Makanan Ternak, Fakultas Peternakan, Institut Pertanian Bogor. Skripsi. Sarjana Peternakan. Bogor.

Scott, M. L., M. C. Nesheim dan R. J. Young. 1982. Nutrition of the Chicken. 3rd Ed. ML. Scott and ASS. Ithaca.

Setiowati, A. N. 2001. Pengukuran Retensi Nitrogen dan Enargi Metabolis Kayambang (Salvinia molesta) Pada Itik Lokal. Skripsi Jurusan Ilmu Nutrisi dan Makanan Ternak. Fakultas Peternakan Institut Pertanian Bogor.

Tampubolon, B P. 2012. Pengaruh Imbangan Energi dan Protein Ransum terhadap Energi Metabolis dan Retensi Nitrogen Ayam Broiler. eJurnal Mahasiswa Universitas Padjadjaran 1 (1): 1-7.

Wahju, J. 2004. Ilmu Nutrisi Ternak. Gajah Mada University Press. Yogyakarta.

Wicaksono, D. Kurtini, T, dan Nova, K. 2015. Perbandingan Fertilitas, Susut Tetas, Daya Tetas, dan Bobot Tetas Ayam Kampung pada Peternakan Kombinasi. JIPT 1(2): $1-8$. 
Zaman, Q. Suparno, G., dan Hariani, D. 2013. Pengaruh kiambang (Salvinia molesta) yang difermentasi dengan ragi tempe sebagai suplemen pakan terhadap peningkatan biomassa ayam pedaging. LenteraBio: Berkala Ilmiah Biologi 2(1): 131-137.

Zulfanita, Roisu, E. M., Dyah P. U. 2011. Pembatasan Ransum Berpengaruh terhadap Pertambahan Bobot Badan Ayam Broiler pada Periode Pertumbuhan. Mediagro: Jurnal Ilmu-Ilmu Pertanian 7 (1): $60-67$. 